\title{
Cooperativism and Microcredit: an analysis of the participation of cooperatives in
}

\section{the supply of microcredit in Brazil}

\author{
Cooperativismo e Microcrédito: uma análise da participação das cooperativas na oferta de \\ microcrédito no Brasil \\ Cooperativismo y Microcrédito; un análisis de la participación de las cooperativas en la oferta de \\ microcrédito en Brasil
}

Received: 01/09/2022 | Reviewed: 01/13/2022 | Accept: 01/20/2022 | Published: 01/22/2022

\author{
Ana Lucia Carvalho Santos \\ ORCID: https://orcid.org/0000-0003-1116-5292 \\ Universidade Estadual de Feira de Santana, Brazil \\ E-mail: analucia@uefs.br \\ Elise Soerger Zaro \\ ORCID: https://orcid.org/0000-0002-3235-719X \\ Universidade Federal da Grande Dourados, Brazil \\ E-mail: elisezaro@ufgd.edu.br \\ José Renato Sena Oliveira \\ ORCID: https://orcid.org/0000-0001-9820-4682 \\ Universidade Estadual de Feira de Santana, Brazil \\ E-mail: jrsenna@uefs.br
}

\begin{abstract}
This study analyzes the participation of Brazilian credit unions in the provision of microcredit in the period from 2017 to 2019. The cooperatives belonging to the four main cooperative credit systems in the country were considered: Cresol, Sicoob, Sicredi and Unicred. To meet the proposed objective, a documentary research was carried out as from the survey of secondary data from official agencies, in addition to data from the financial and accounting reports of the analyzed institutions. The literature consulted points out that credit unions have a greater incentive to carry out solidarity credit and microcredit operations, given their social nature. The results presented evidence that the microcredit offer by the analyzed cooperative systems is not very significant, representing, on average, less than $10 \%$ of the total microcredit portfolio in the analyzed years. The main conclusion is that most Brazilian credit unions, with the exception of those that compose the solidarity segment, have not had a significant participation in the supply of microcredit. It is hoped that these findings can contribute to the development of policies capable of changing this picture, that is, that these institutions, considered by the literature as the ideal model of organization to operate microcredit, can potentialize actions towards a greater insertion in the supply of microcredit.
\end{abstract}

Keywords: Brazilian Credit Unions; Solidary credit; Documentary survey; Accounting reports; Microcredit.

\section{Resumo}

Este estudo analisa a participação das cooperativas de crédito brasileiras na oferta de microcrédito no período de 2017 a 2019. Foram consideradas as cooperativas pertencentes aos quatro principais sistemas de crédito cooperativo do país: Cresol, Sicoob, Sicredi e Unicred. Para atender ao objetivo proposto, realizou-se uma pesquisa documental a partir do levantamento de dados secundários junto a órgãos oficiais, além de dados dos relatórios financeiros e contábeis das instituições analisadas. A literatura consultada aponta que as cooperativas de crédito têm maior incentivo para realizar operações de crédito solidário e de microcrédito, dada a sua natureza social. Os resultados apresentaram evidências de que a oferta de microcrédito pelos sistemas cooperativistas analisados é pouco significativa, representando, em média, menos de $10 \%$ do total da carteira de microcrédito nos anos analisados. A principal conclusão é que a maioria das cooperativas de crédito brasileiras, com exceção das que compõem o segmento solidário, não tem tido uma participação significativa na oferta de microcrédito. Espera-se que esses achados possam contribuir com o desenvolvimento de políticas capazes de mudar esse quadro, ou seja, que estas instituições, consideradas pela literatura como o modelo ideal de organização para operar o microcrédito, possam potencializar ações em direção a uma maior inserção na oferta de microcrédito.

Palavras-chave: Cooperativas de Crédito Brasileiras; Crédito solidário; Pesquisa documental; Relatórios contábeis; Microcrédito. 


\section{Resumen}

Este estudio analiza la participación de las cooperativas de crédito brasileñas en la concesión de microcréditos en el período comprendido entre 2017 y 2019. Se consideraron las cooperativas pertenecientes a los cuatro principales sistemas de crédito cooperativo del país: Cresol, Sicoob, Sicredi y Unicred. Para cumplir con el objetivo propuesto, se realizó una investigación documental a partir del relevamiento de datos secundarios de organismos oficiales, además de datos de los informes financieros y contables de las instituciones analizadas. La bibliografía consultada señala que las cooperativas de crédito tienen un mayor incentivo para realizar operaciones de crédito solidario y microcrédito dado su carácter social. Los resultados mostraron evidencias de que la oferta de microcrédito por los sistemas cooperativistas analizados es poco significativa, representando, en promedio, menos del 10\% del total de la cartera de microcrédito en los años analizados. La principal conclusión es que la mayoría de las cooperativas de crédito brasileñas, con excepción de las que componen el segmento solidario, no han tenido una participación significativa en la oferta de microcrédito. Se espera que estos hallazgos puedan contribuir al desarrollo de políticas capaces de cambiar este panorama, es decir, que estas instituciones, consideradas por la literatura como el modelo ideal de organización para operar el microcrédito, puedan potenciar las acciones hacia una mayor inserción en la oferta del microcrédito.

Palabras clave: Cooperativas de Crédito Brasileñas; Crédito solidario; Investigación documental; Informes contables; Microcrédito.

\section{Introduction}

With the current economic crisis triggered by the Covid-19 pandemic, financial assistance to the vulnerable and workers, as well as the provision of credit to micro and small businesses and to micro and small individual entrepreneurs, has become a worldwide need. In the case of Brazil, the Federal Government created three financial assistance programs during the pandemic: (I) emergency aid, aimed at the unemployed and informal workers; (II) The National Support Program for microenterprises and small businesses (Pronampe), a credit line intended to finance small businesses, individual microentrepreneurs (MEIs) and small businesses (working capital); and (iii) the emergency access to Credit Program (Peac), aimed at small and medium-sized companies (working capital or investment). These examples illustrate the relevance of microcredit in times of crisis and how the proper use of this tool can contribute to boosting economic activity.

A survey by the Brazilian Service of Support for Micro and Small Enterprises (Sebrae) in partnership with the Getúlio Vargas Foundation (FGV), conducted at the beginning of the pandemic (April and May 2020), revealed that it is easier to get credit in cooperatives than in banks. The success rate for obtaining credit in cooperative institutions was $51 \%$ of respondents, $26 \%$ in the cooperatives of the Sicoob cooperative credit system and 25\% in the Sicredi system (Sebrae/FGV, 2020).

From a theoretical point of view, the cooperativism is based on utopian socialism (Pinheiro, 2008), and proposes to be a third way before the dichotomy capitalism x socialism and it is precisely for this reason that in crises the cooperativism is strengthened. The history of cooperativism has corroborated this view, and cooperativism enthusiasts consider it to be the business model best prepared to face economic crises.

Previous studies have found evidence that credit unions are less sensitive to the volatility of the financial market and economic cycles, and thus tend to mitigate contractionist effects during crises (Mckillop et. al., 2020) and, in addition, tend to respond to crises differently from other institutions (Lu \& Swisher, 2020).

Aghabarari et. al. (2020), when analyzing data from the National Cooperative Credit System (SNCC) in the context of the 2008 crisis, also identified that cooperatives tend to restrict less lending during periods of recession by mitigating liquidity shocks, with positive effects on small and medium-sized enterprises and also on the level of employment.

Research commissioned by the System of Cooperative Credit (Sicredi) to the Foundation Institute of Economic Research (FIPE) evaluated economic data of all Brazilian municipalities (with and without cooperative institutions) between 1994 and 2017 and identified that credit cooperativism is a fairly effective mechanism to promote financial inclusion, as it enables people to access financial products and services in smaller and more distant municipalities. This study also concluded that credit cooperativism is able to increase the GDP per capita of Brazilian municipalities by $5.6 \%$ and can create up to $6.2 \%$ 
more formal jobs than other segments (FIPE/ Sicredi, 2019).

Despite the observation of the aforementioned researches about the relevance of credit cooperative, Santos et. la. (2019) identified a small participation of cooperatives in the supply of microcredit in Brazil between 2008 and 2014, despite some government programs and resolutions of the National Monetary Council (CMN) and the Central Bank of Brazil (BCB), which significantly increased the supply of microcredit in the period by different types of financial and non - financial institutions, especially productive microcredit-which aims to finance economic activities and has some public programs.

The research of Santos et. la. (2019) also identified that the solidarity segment of cooperativism had a greater role in the supply of microcredit. Thus, the present study aimed to analyze the insertion of Brazilian credit unions in the microcredit offer in Brazil in the period from 2017 to 2019. More specifically, we sought to identify whether there was a difference in the volume of microcredit offered by credit cooperatives in the solidarity segment compared to the traditional segment of these cooperatives. It is argued that the inclusion of Solidarity Credit Cooperatives in the microcredit offer is greater than that of traditional cooperatives, considering that the former prioritize social objectives, even without disregarding the economic aspect.

This study is justified to the extent that, despite the representativeness of the credit cooperative segment in terms of number of institutions, in addition to its relevance ratified by the literature (Barreto, 2016; Burigo, 2006; Christopoulos \& Gonzalez, 2017; Pinheiro, 2008; Pinho, 2004) and empirical studies (Confebras, 2020; FIPE/Sicredi, 2019; Sebrae/FGV, 2020) in relation to the provision of microcredit, is less relevant to other types of financial institutions (Santos, 2016; Santos et. al., 2019).

The results of this study pointed out that, although, historically, credit unions prove to be the most appropriate institutional model to serve municipalities and small enterprises, the offer of microcredit by these organizations during the analyzed period (2017 to 2019) proved to be insignificant. This finding suggests that these cooperative institutions need to increase their participation in the offer of microcredit, although some cooperatives present in their reports and in their sustainability agendas projects and intentions to increase the insertion of the segment, both in the provision of micro-credit and in the diversification of microfinance products and services.

\section{Literature Review}

\subsection{Credit Cooperativism}

The spirit of cooperation is deeply human, and it can be found in the most primitive societies (Pinheiro, 2008). However, it was in the environment of the 1st Industrial Revolution, when capitalism imposed its mercantile logic, that cooperativism started to crystallize in more formal terms, appearing as a mechanism of resistance of those who sought survival alternatives in face of the growing exploitation of workers - artisans and peasants (Burigo, 2006).

Cooperativism is a practice found in almost all primitive peoples, but the so-called modern cooperativism is attributed to the creation of the 1st cooperative (consumer) that occurred in 1844, in the English city of Rochdale, in response to the employment crisis caused by the Industrial Revolution (Burigo, 2006). Since then, credit cooperativism grew, especially in Europe, where this movement is stronger until today (Santos et. al., 2019).

According to the International Cooperative Alliance (ICA, 2020), a cooperative is an autonomous association of people united voluntarily to pursue their common needs and aspirations, whether economic, social, or cultural, through a democratically controlled common enterprise. This definition preserves the founding principles of the cooperative movement as autonomy and participation, stressing that the needs or aspirations it aims to satisfy are not only of an economic nature, but also of a social and cultural nature (Namorado, 2009). In Brazil, cooperative societies are governed specifically by Complementary Law 130/2009, and subsidiarily by Law 5.764/1971. 
The principles of cooperativism were defined by the "Rochdale Pioneers", still in the 19th century, but they are still being updated by the International Cooperative Alliance, in meetings that took place in 1937, 1966 and 1995. They are (i) Free and voluntary membership; (ii) Management and democratic control of the associates ("one member, one vote"); (iii) Economic participation of the associates (surpluses are socialized); (iv) Autonomy and independence; (v) Education, training and information: (vi) Intercooperation (partnership among cooperatives); (vii) Interest and concern for the community (ICA, 2020).

With regard to typification or branches of cooperativism, Law 5,764/1971, which established the legal regime of cooperative societies and their characteristics, also defined their types. In April 2019, the Organization of Brazilian Cooperatives (OCB) launched a booklet with the reorganization of the branches of cooperativism, which went from 13 to 7. Some branches united, others were re-signified, like the new branch "Labor, Production of Goods and Services", former "Work", which incorporated the old branches "production", "mineral", part of "tourism and leisure" beyond the "special" considered that the main change in the modernization process. Thus, the types of cooperatives today are: agriculture; consumption; credit; infrastructure; health; labor, production of goods and services; and transport (OCB, 2020). This research dealt exclusively with the credit segment.

Credit cooperativism arises from experiences of financial assistance to the poor, according to Burigo (2006), like revolving funds, and begins in Europe during the eighteenth century. In Brazil, the first cooperative appeared in Ouro Preto, Minas Gerais, in 1889 and in 1902, in Rio Grande do Sul, the Swiss priest Theodor Amstadt, created the first credit cooperative called Nova Petrópolis Rural Cashier, inspired by the German experience (Pinheiro, 2008; Christopoulos \& Gonzalez, 2017). The German "model" of credit cooperative was created by Raiffeisen in the mid-nineteenth century, and became known as the "people's bank", based on loans characterized by: (i) residence of policyholders in small rural communities; (ii) assurance by members and co-responsibility by peers (Bastelaer, 2000). From the 1990s onwards, credit unions consolidated with the emergence of cooperative credit systems.

Credit unions are considered a potential instrument in the fight against financial exclusion, as they provide loans in ways and places where other financial institutions cannot reach (Ward \& McKillop, 2005). Moreover, in the specific case of Brazil, there is a high concentration in the banking segment and these traditional financial institutions do not consider it economically interesting to operate in municipalities with less than 50,000 inhabitants. On the other hand, data from BCB (2020b) point out that by the end of 2020, singular credit cooperatives were located in 1,367 different municipalities, almost $90 \%$ with less than 50,000 inhabitants.

However, Goldszmidt et al. (2021) made a large-scale evaluation of the impact of microcredit in Brazil using primary data and analyzed the microcredit impacts for 16 different microfinance institutions (MFIs) in two vast macro-regions: Northeast and South. The Northeast of Brazil is poorer, and the South is rich. The only treatment effect found was among businesses located in areas with lower levels of human development in the Northeast. In this subset of participants, old beneficiaries have higher sales and fewer months in which the revenues were lower than costs compared to the control group.

Pinho (2004) points out that credit unions differ from commercial banks in that they reapply the savings of members in their own region, thus contributing to stimulate their development and, at the same time, correct regional imbalances.

McKillop and Wilson (2010), when reviewing the academic literature on credit unions around the world, identified, among others, another relevant contribution of this segment, which is its ability to circumvent problems of imperfect information, given that by doing business exclusively with members, they create a bond between the institution and the member, and this bond is based on a pre-existing social connection (such as belonging to a particular community, for example). 
On the other hand, when comparing consumer microcredit and the productive and oriented microcredit offered to lowincome entrepreneurs, Feitosa et al. (2022) found that the consumer credit borrower generates less value for the institution than the productive microcredit borrower, especially because productive microcredit has a lower default rate and a higher renewal rate. In addition, the study also showed that productive microcredit presents itself as the best alternative financing for lowincome micro-entrepreneurs mainly because the amounts are more appropriate to the actual cash flow of those entrepreneurs.

\subsection{Solidarity credit cooperativism}

The solidary aspect of cooperativism (Pinho, 2004) also called the horizontalized segment (Alves \& Soares, 2004), emerges within the cooperative movement based on social movements and on a logic of network action, with its service aimed at low-income segments, which is conventionally called solidary cooperativism (Santos et. al., 2019).

Based on a case study and in an institutionalist perspective, Alves Júnior et al. (2021) analyzed the sociopolitical processes underlying the constitution of the solidary credit cooperativism in Zona da Mata Mineira and how they influenced the constitution process of these financial organizations. They concluded that the process promoted by the social actors involved in the trajectory of the organizations that gave origin to the solidarity credit cooperative in Minas Gerais did not represent only a rational strategy to expand the financial performance. In this sense, this organizational model emerges from relationships linked to other elements and influences from institutions, such as the church and trade unions. Thus, the process promoted by these social actors gave support to a model for credit cooperativism, horizontal and developed from a solid and cohesive social base. Also, it brought social parameters of action to the technical and elitist National Financial System, under which traditional financial agents were not willing to act.

The solidary credit cooperativism is also called "alternative" because it is an option to the "traditional credit cooperativism". The term "alternative", which initially characterized this type of cooperatives, is gradually being replaced by the adjective "solidary" (Schroder, 2005).

Traditional or verticalized cooperativism (Soares \& Melo Sobrinho, 2008) is organized under a centralized and pyramidal structure - with singular cooperatives, central offices, and the confederation as the central power - and are represented in Brazil by the cooperative credit systems: Cooperative of Rural Credit with Solidarity Interaction (Cresol), Credit Cooperative System of Brazil (Sicoob), Cooperative Credit System (Sicredi) and Union of Credit Cooperatives (Unicred). The horizontal systems (solidary), on the other hand, are organized in the form of networks, thus differentiating themselves from the operating patterns of vertical cooperatives, although they also have central offices and a confederation. This aspect of cooperativism gained greater expression with the establishment of the National Union of Family Farming and Solidarity Economy Cooperatives (Unicafes) in 2005, which became the national entity for the political representation of solidarity cooperativism (Freitas \& Freitas, 2014).

In this perspective, the solidarity credit cooperatives, together with the people's banks and the revolving funds, among other organizations and programs of this nature, form the movement called solidarity finance and this movement questions the role of large cooperatives as to the ability to serve the less favored social strata and tries to rescue the principles elaborated by the precursors of cooperativism in the eighteenth and nineteenth centuries (Barreto, 2016; Burigo, 2006; Schroder, 2005).

The main characteristics of cooperatives of solidarity interaction are: (i) arose from intense social and political mobilizations of family farming and its representative organizations; (ii) the principles that guide them are directly associated with the maintenance of solidary relations, through credit, going beyond a strictly financial action; and (iii) their operation takes place in a differentiated way, valuing the proximity and trust with the cooperated (Freitas \& Freitas, 2014). 
Credit unions are aligned with the broader movement called solidarity economy. The solidarity economy, in turn, proposes that the whole set of economic activities - production, distribution, consumption and credit - be organized in a selfmanaged way, prioritizing cooperation, fair trade and conscious consumption.

In Brazil, the experiences of cooperative solidarity emerged in the first half of the 1990s, simultaneously in the west of Santa Catarina and the southwest of Paraná (the Cresol System) and in the semi-arid region of Bahia the Association of Cooperatives of Support to the Family Economy (Ascoob), having these cooperatives acted especially in the rural environment (Búrigo, 2006).

From the 1990s on, with the emergence and growth of organizations such as Ascoob and Unicafes, the cooperative solidarity segment also expanded into the urban sphere.

\subsection{Cooperativism and Microcredit}

Microcredit is inserted in an even more current and comprehensive concept, which is the microfinance approach. Microfinance, in turn, includes all financial services such as loans, savings, insurance, credit cards, and others, aimed at the low-income population, and microcredit is the main microfinance service (Barone; Sader, 2008). As for the productive and oriented microcredit (MPO), for these authors, it is the one directed to micro and small formal and informal enterprises and, in principle, it is not intended to finance consumption. The main characteristics of the MPO are: (i) the joint and several guarantee, which consists of peer monitoring among members of a group of borrowers jointly responsible; (ii) the analyzis and monitoring by a credit agent; (iii) the progressivity of loan amounts; (iv) the periodicity of payments and; (v) credit empowerment (Santos et. al., 2019).

It is understood, therefore, that microcredit is not small credit, but a practice that should be developed considering these methodologies historically constituted and referenced by successful practices, such as the Grameen bank in Bangladesh, responsible for the dissemination of the modern concept of microcredit worldwide.

Microcredit emerges concomitantly with credit unions in the 19th century (Christopoulos \& Gonzalez, 2017), although contemporary microfinance and microcredit experiences emerged in the mid-1970s from parallel movements in Latin America and Asia (Aghion \& Morduch, 2005). Group lending, considered the main characteristic of microcredit, is attributed to the credit cooperatives created by Raiffeisen in Germany (Bastelaer, 2000).

In Brazil, the first microcredit experience began in the 1970s, more specifically in 1973, when the Nordestina Union for Assistance to Small Organizations (UNO) began its activities, although it was only from the 1990s that the actions, policies and programs targeted at microfinance and micro-credit intensify. According to Barone and Sader (2008), microcredit policies and programs in Brazil have emphasized the MPO. Among them, we highlight the National Program of Oriented Productive Microcredit (PNMPO), created in 2005 and revised in 2011 (CRESCER Program), the largest and most important microcredit program to date and whose Law of Pnmpo ( $\mathrm{n}^{\mathrm{o}}$ 11,110/2005) included credit unions as operating institutions (Santos et. al., 2019).

The Pnmpo was created in 2005 and, since then, has undergone several modifications, considered by BCB (2020) as improvements, among them, the expansion of the target audience, harmonizing it with the legal concept of microenterprise; more intense use of digital technologies and the permission of non-presence attendance by the credit agent, authorization of non-financial institutions to grant on-lending operations, the simplification of access to financial products and services for MEI (Credmei) - electronic platform of financial services aimed at this public -, besides the most recent changes promoted by Law no. 13. 636/2018, Provisional Measure no. 905/2019 converted into Law no. 13.999/2020 that expanded the Pnmpo limit. Between 2005 and 2019, some normative adjustments were made in the Program, such as the prioritization of low-income segments. As of 2019, there was the redefinition of microcredit as a set of 71 modalities of credit operations for an established 
target audience, normative improvements for the reduction of costs, besides the incorporation of new technologies and specialized entities. Between 2017 and 2019, the period of analyzis, there were also two increases in the income limit for access to microcredit - the first, via a BCB rule, raising the limit from $\mathrm{R} \$ 120$ thousand to $\mathrm{R} \$ 200$ thousand and the second, in the provisional measure that established the new Pnmpo, which rose from $\mathrm{R} \$ 200$ thousand to $\mathrm{R} \$ 360$ thousand (BCB, 2020).

Authors such as Bastelaer (2000) and Ward and McKillop (2005) have analyzed the relationship between microcredit and cooperativism. Bastelar (2000) attributes the main microcredit methodology or technology, namely, group lending - which has become world-renowned more recently from the Grameen Bank experience - to the credit cooperatives created by Raiffeisen in Germany in the mid-19th century. This cooperative model, also known as "people's bank", used as criteria for the practice of group loans the residence of borrowers in small rural communities, the guarantee by the members (solidary guarantee) and the co-responsibility of peers for the loans (Bastelaer, 2000). Ward and McKillop (2005) point out that some specificities of credit unions, such as capillarity - they are distributed throughout the national territory, reaching even the most distant and less economically favored municipalities -, contribute to reducing information asymmetry, since it allows them to offer products and services in places where other financial institutions do not reach.

According to McKillop et. al. (2020), credit unions play an important role in the financial systems of many countries around the world, since they are present in over 140 countries and are important sources of credit, especially for small and medium-sized companies. The authors also add that in times of crisis, while traditional banks usually restrict credit to families and businesses, the cooperatives generally extend it.

Solidarity finance refers to the constitution of forms of democratization of the financial system that prioritize those excluded from the traditional banking system, and that have their actions guided by ethics and solidarity (Coelho, 2003). For this author, microfinance, and microcredit in particular, breaks the functional vision of financial intermediation and the concept of solidarity finance expands the notion of microfinance.

Indeed, credit unions are fundamental in this process of financial intermediation, both from the traditional point of view and in financial relations with solidarity. Data from the BCB (2019b) show that the total adjusted assets of the SNCC grew $16.2 \%$ in the period between 2015 and 2019. Already in the period between 2016 and 2020, the SNCC grew at rates higher than the rest of the National Financial System (SFN) - the participation of the total assets of the SNCC in relation to the SFN went from 2,5\% to 3,8\% in the period; the participation of the credit portfolio, from $2.7 \%$ to $5.1 \%$ and the participation in the volume of deposits, from $5.1 \%$ to $6.2 \%$ - (BCB, 2020b). Also, according to this report, the growth of the Brazilian cooperative sector has been showing a long-term trend - between 2011 and 2015, the total credit portfolio increased from $\mathrm{R} \$ 47.04$ billion (2.43\% of SFN) to $\mathrm{R} \$ 102.37$ billion (3.23\% of SFN) and this growth occurred not only in the credit portfolio, but also in other banking and financial intermediation services, partly due to the increase in the digital integration of cooperatives.

BCB (2020) also identified that the growth of SNCC's credit portfolio in relation to the SFN was more significant in the rural segment, which in December 2020 corresponded to 20.26\% of the SFN's rural financing. In December 2020, the main type of credit granted by the SNCC to individuals was rural credit, whose balance represented $36.9 \%$ (BCB, 2020b). As the Cresol system analyzed in this study has its main product in rural credit, the expectation is that this system presents greater participation in credit in general and, above all, in microcredit given its solidary character.

\section{Material and Methods}

This study is an applied research, since it investigates a concrete social problem. Regarding the database, it is a documentary study, with a quantitative approach, based on secondary data collection. Regarding the objective, it is a descriptive research, considering that narrates and interprets a phenomenon without interfering with it. 
Regarding the documentary strategy, according to Martins \& Theóphilo (2007), it is worth using primary sources, data compiled by the author himself and that have not yet been analyzed or that can be reworked according to the purposes of the research. From this perspective, data were collected for this research by the BCB and the Brazilian cooperative credit systems Cresol, Sicoob, Sicredi and Unicred. The BCB and cooperative systems data were collected through the financial reports (Accounting Statements and Sustainability Reports) published on the websites of the respective Financial Institutions (FIs) that make up the respective systems. Based on this information, tables and graphs were constructed in order to support the analyzis performed in the present study.

\subsection{Characterization of the population: the Brazilian cooperative credit systems}

According to the FIPE/Sicredi survey (2019), the SNCC is structured as follows: (i) four third-level credit cooperative systems (they have their own legal personality, bring together a confederation and at least 3 central cooperatives); (ii) five organized second-level systems (consisting of centrals and at least three singular cooperatives); (iii) credit cooperatives not affiliated to centrals (independent).

This study chose to analyze the credit cooperative systems at the third level because they are more complete: they have a larger number of affiliated cooperatives, greater diversification of products and services, and greater territorial coverage. The third level cooperative credit systems analyzed here are: Cresol, Sicoob, Sicredi and Unicred.

\subsection{Research population}

The population analyzed for this research were all the singular cooperatives, branches and service stations that appear in the reports published by the four Brazilian cooperative systems at three levels: Cresol. Sicoob, Sicredi and Unicred.

As previously mentioned, we chose to analyze the credit unions belonging to the three-tier systems because they are more complete and larger in terms of number of affiliated cooperatives, number of members and number of municipalities served. Table 1 shows a greater detailing of each of these systems. 
Table 1: Credit Union systems at three levels: Cresol. Sicoob, Sicredi and Unicred.

\begin{tabular}{|c|c|}
\hline Cresol & $\begin{array}{l}\text { The data analyzed in this research were collected from the Cresol Confederation. The Cooperative System of Rural Credit with } \\
\text { Solidarity Interaction (Cresol) emerged in the late 1980s, from the experience of a Revolving Credit Fund of small farmers and agrarian } \\
\text { reform settlers in the Southeast and Midwest regions of Parana and in Santa Catarina and Rio Grande do Sul (Cresol, 2020). } \\
\text { Today called the Cresol Baser system covers } 17 \text { states, has more than 550,000 members and aims to increasingly promote financial } \\
\text { inclusion and social development in each region where it operates, and is currently considered the largest rural solidarity credit } \\
\text { cooperative system in Brazil and the fourth largest among all cooperative credit systems in the country (Cresol, 2019). } \\
\text { Among the products and services offered by the Cresol system, revolving credit, acquisition of movable goods, real estate and } \\
\text { services stand out, however, the main product of the system is rural credit, which has accompanied and strengthened Cresol during its } \\
\text { trajectory and has always represented the largest volume of credit operated by Cresol cooperatives. The rural credit lines offered by } \\
\text { Cresol to producers are financed with its own resources and also with onlendings from official credit lines regulated by the National Rural } \\
\text { Credit System (SNCR), derived from Law No. } 4,595 / 1964 \text { (Cresol, 2019). Cresol also operates with onlendings of official resources from } \\
\text { the National Bank for Economic and Social Development (BNDES) and other institutions (interfinancial and intercooperative deposits). } \\
\text { Taking into account the characteristics of solidarity credit cooperatives presented by Freitas \& Freitas ( } 2014) \text {, it was deemed } \\
\text { appropriate, for the purposes of this research, to consider the entire supply of credit made possible by the Cresol system as microcredit. } \\
\text { In addition, the cooperatives that make up the system are inserted in medium and small municipalities (average population of } 30,000 \\
\text { inhabitants) and, furthermore, their members are family farmers and salaried urban workers. Another factor that led to the decision to } \\
\text { consider all the credit offered by the Cresol system as microcredit is the fact that the cooperatives belonging to this system use one of the } \\
\text { most important microcredit methodologies, namely, the oriented credit (Cresol, 2019). }\end{array}$ \\
\hline Sicoob & $\begin{array}{l}\text { The data from the Sicoob Cooperative Credit System analyzed by this research also belong to the Sicoob Confederation, which was } \\
\text { founded in } 2002 \text { (www.sicoob.com.br). } \\
\text { In addition to the cooperative bank Bancoob and the individual and central cooperatives, the Sicoob system is also composed of } \\
\text { controlled companies and their subsidiaries (companies/entities of: electronic means of payment, consortiums, DTVM - Distribuidora de } \\
\text { Títulos e Valores Mobiliários -, insurance and pension plans) that provide specialized products and services for financial cooperatives } \\
\text { (Sicoob, 2019). Sicoob is, today, the largest cooperative financial system in the country and the only one with operations in all states of } \\
\text { Brazil (Sicoob, 2019; Confebras, 2020; BCB, 2019). }\end{array}$ \\
\hline Sicredi & $\begin{array}{l}\text { The Sicredi cooperative credit system is the oldest cooperative system in Brazil and includes the first cooperative financial institution } \\
\text { in Brazil. It is composed of a confederation (founded in 2000), five regional central cooperatives, a foundation, a cooperative bank and its } \\
\text { subsidiaries. It has a very diversified portfolio of financial products and services that include: foreign exchange, credit and debit cards, } \\
\text { consortiums, investments, social security, payments and receipts, savings, insurance, and even derivatives. Its actions are more } \\
\text { concentrated in the Southern (where it started) and Southeastern states, although it has expanded its presence to the current } 23 \text { Brazilian } \\
\text { states (and the Federal District) in which it is present (Sicredi, 2019). } \\
\text { The Sicredi system is one of the most representative of the "traditional" cooperative model, given that it is organized in a vertical, } \\
\text { centralized manner and aims for gains by scale (Freitas \& Freitas, 2014). } \\
\text { Furthermore, historically, it was part of the process of insertion of the credit cooperatives as financial agents of the agricultural } \\
\text { cooperatives in the South and Southeast of Brazil. This process led the former to follow the strategies of the latter, largely benefiting the } \\
\text { more capitalized farmers (Burigo, 2006; Schroder, 2005). Still according to Burigo (2006), this process was due to the co-optation of a } \\
\text { large part of the Brazilian cooperativism by the government (especially the military government), which historically controlled } \\
\text { cooperatives in general, including the credit cooperatives, to prevent them from becoming instruments of political emancipation and } \\
\text { empowerment of the less favored classes, and thus led most cooperatives to dissociate themselves from the original principles of } \\
\text { cooperativism. }\end{array}$ \\
\hline Unicred & $\begin{array}{l}\text { The cooperative credit system Unicred appeared in 1989, in Rio Grande do Sul. Initially, it served the area and health professionals, } \\
\text { but today, it has a much more comprehensive operation, currently with four central cooperatives, besides the singular cooperatives and a } \\
\text { confederation, founded in } 1994 \text { (Confebras, 2020). In 2020, it had } 35 \text { unique cooperatives, approximately } 280 \text { business units in } 15 \\
\text { Brazilian states and more than } 220,000 \text { cooperated (www.unicred.com.br). The data collected and analyzed in this study are from the } \\
\text { Unicred Confederation. }\end{array}$ \\
\hline
\end{tabular}

Source: Elaborated by the authors based on data from the financial reports of the confederations.

The Table 2 shows the size and scope of each of these systems.

Table 2: Size and scope of the Brazilian cooperative credit systems: Cresol, Sicoob, Sicredi and Unicred - 2019.

\begin{tabular}{l|c|c|c|c}
\hline & CRESOL & SICOOB & SICREDI & UNICRED \\
\hline Number of Members/Cooperators & 553.000 & 4.629 .429 & 4.466 .750 & 220.000 \\
Number of States in which they operate & 17 & 27 & 23 & 15 \\
Number of municipalities where they are present & 1.877 & 1.859 & 1.378 & $\mathrm{NI}$ \\
Municipalities as the only Financial Institute & $\mathrm{NI}$ & 302 & 210 & $\mathrm{NI}$ \\
\% of municipalities with <100 thousand inhab. where they are present & $\mathrm{NI}$ & $61 \%$ & $87 \%$ & $\mathrm{NI}$ \\
Number of Agencies/Service Stations (Pas) & $\mathrm{NI}$ & 3.283 & 1.861 & 280 \\
Number of Individual Cooperatives $^{1}$ & 548 & 396 & 110 & 35 \\
\hline
\end{tabular}

${ }^{1} \mathrm{BCB}$ data (2020b) show 79 individual cooperatives in the Cresol system. Source: Elaborated by the authors based on data from the financial reports of the confederations.

As can be observed in Table 2, the Sicoob system is the largest in number of cooperators and states in which it operates. In relation to the number of municipalities in which they are present, the cooperatives of the Cresol system are listed 
first. The Unicred system is the least representative in terms of the number of co-operatives, the number of states in which they operate and the number of individual co-operatives, in addition to not presenting a series of information in their reports, including on the offer of microcredit. Sicredi is the most present system in municipalities with less than 100,000 inhabitants, although it is concentrated in the South and Southeast regions.

\section{Results and Discussion}

As described previously, Brazil has four Brazilian cooperative credit systems at three levels (composed of singular cooperatives, central cooperatives, and confederations), namely: Cresol, Sicoob, Sicredi and Unicred. Of these, only Sicredi presents separate microcredit supply data in its reports. The Unicred system makes no mention of microcredit in its reports. As for the Cresol system, as was seen, it is a cooperative solidarity credit system, and although it does not present separate data in its financial reports, it emphasizes in all documents analyzed that microcredit is in its essence. Sicoob, on the other hand, showed specific data on the supply of microcredit only in the year 2018.

In Cresol's 2017 report, the statement appears that microcredit is fundamental to the advancement of the economic and social organization of family farmers and that Cresol started to seek partnerships to leverage resources for the program (Cresol, 2017) but there is also no report on the offer of microcredit. no document 2018, the report is restricted to the amount of the transfer of BNDES resources, and states that Cresol occupied the 6th position in the ranking of indirect transactions physical person BNDES, with transfers of more than $\mathrm{R} \$ 1,1$ billion in approximately 40 thousand rural credit and microcredit operations (Cresol, 2018), but there is no mention of the other modalities of resources used in microcredit operations. In the 2019 report, nothing was mentioned about the offer of microcredit specifically.

As already mentioned, this study chose to consider the entire credit portfolio of the Cresol system as microcredit by the characteristics of the system identified in its reports (Cresol, 2017; Cresol, 2018; Cresol, 2019) and referenced by the literature consulted (Bittencourt \& Abramovay, 2003; Bittencourt, 2001; Burigo, 2006; Freitas \& Freitas, 2014; Schroder, 2005; Soares \& Melo Sobrinho, 2008). In addition, the main product of the system is rural credit aimed at family farmers, a segment that in Brazil is composed predominantly of small enterprises.

The Figure 1 shows the microcredit portfolio, total assets and total volume of deposits of the Cresol system.

Figure 1: Total Assets/Resources managed, volume of deposits and balance of the microcredit portfolio (in R $\$$ billion) Cresol1 - 2017 to 2019.

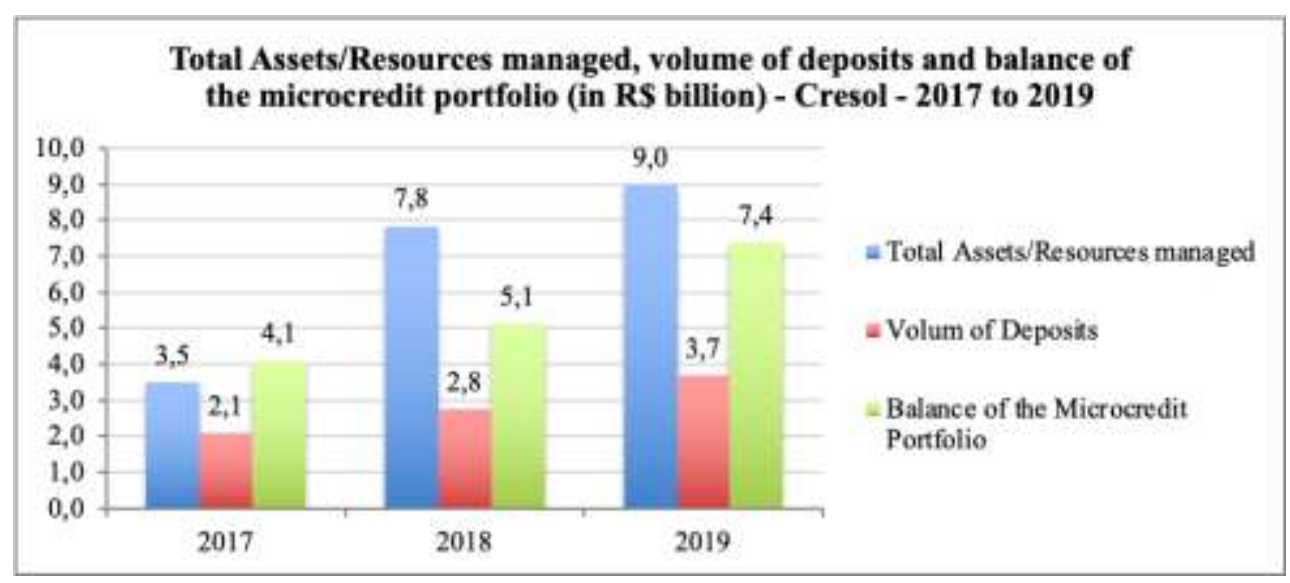

${ }^{1}$ Data from Cresol Confederation (Credit Centers: Cresol Baser, Cresol Central SC/RS, Cresol and Ascoob). *Microcredit balance in 2017 refers to: $\mathrm{R} \$ 1.6$ billion of commercial credit and $\mathrm{R} \$ 2.5$ billion of rural credit. ${ }^{* *}$ The balance of microcredit in 2018 refers to: 1.3 billion in on lendings - only from BNDES were 1.1 billion. ${ }^{* * *}$ Microcredit balance in 2019 refers to: $\mathrm{R} \$ 2.7$ billion in commercial credit and $\mathrm{R} \$ 4.7$ billion in Rural/Business on lendings (BNDES and other FIs). Source: Prepared by the authors from data from the confederations' financial reports. 
The Figure 2 shows the percentage share of the microcredit portfolio in relation to total assets and the volume of deposits in the system. As can be observed in this figure, the participation of the microcredit portfolio in relation to the volume of deposits is, on average, almost double. This is due to the transfer of resources from other FIs, such as the BNDES, Cresol's main partner.

Figure 2: Share of Microcredit portfolio in relation to Total Assets and deposit volume in \% - Cresol - 2017 to 2019.

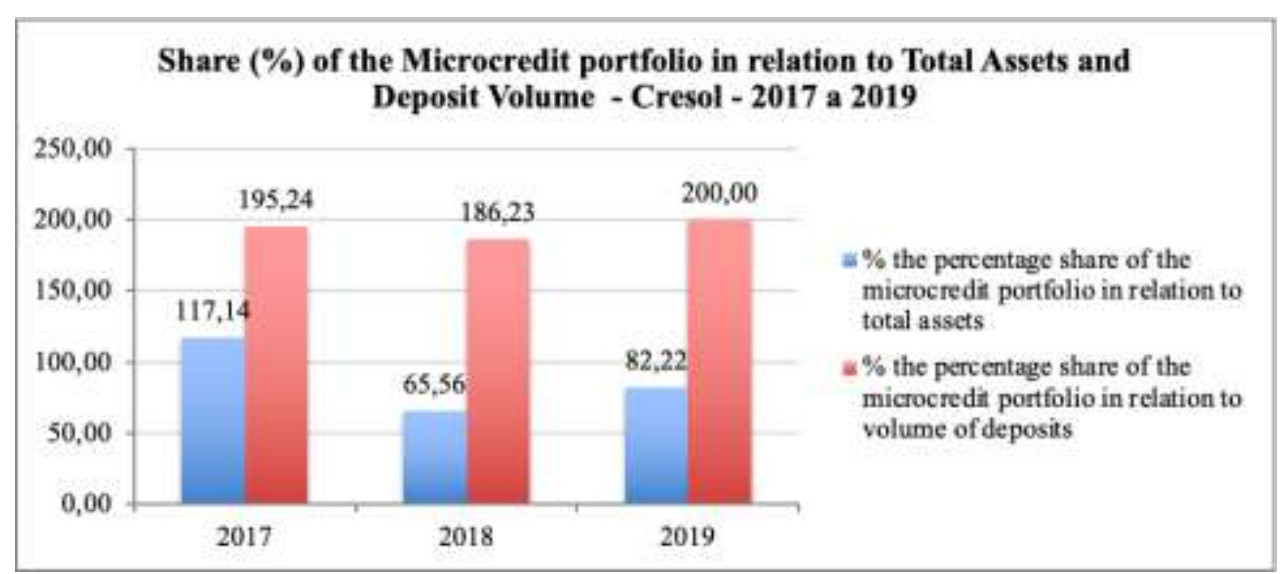

Source: Prepared by the authors based on data from the confederations' financial reports.

Regarding the Sicoob system, although it is the largest in number of members, number of states and municipalities where it operates, number of unique cooperatives, total assets and volume of deposits (see Table 1), the entity recognizes in its 2018 Sustainability Report that the total of its microcredit portfolio was below the target and national guidelines, which imposed "the challenge of better understanding the behavior of demand and the needs of borrowers in this profile, to undertake systemic actions aimed at expanding the participation of this modality" (Sicoob, 2018, p. 71).

Thus, Sicoob, still in 2018, in order to expand the presence of this system in the microcredit segment, prepared a diagnosis in order to map the insertion of its unique cooperatives in offering this type of credit. The result of the survey pointed out that, among the cooperatives that participated in the 2018 Sicoob Social Census (45\% of all singular and central cooperatives), 60\% said they did not operate with an emphasis on microcredit (Sicoob, 2018). In 2019 a new Social Census, which expanded the sample to $75 \%$ of the central and singular cooperatives, identified that the percentage of cooperatives that did not operate with an emphasis on microcredit fell to $35 \%$ (Sicoob, 2019).

Another advance of the Sicoob system in relation to microcredit in 2019 was a partnership between the affiliated Sicoob Credimonte and the Central Única das Favelas (CUFA), which generated a Service Center (PA) in a community, becoming the first financial institution of Minas Gerais within a favela (Sicoob, 2019). On the occasion, microcredit lines were created for microentrepreneurs, which ended up helping professionals such as manicures, hairdressers, street vendors, among others. Until December 2019, the total amount of credit transactions recorded by PA was R \$ 6,148,824.00 (Sicoob, 2019).

Another strategy of the Sicoob system to expand the offer and access to microcredit was the launch, also in 2019, of the Sicoob Microcredit application, with the aim of supporting both the micro-entrepreneur and the cooperative in the negotiation process, thus becoming an important means of financial inclusion (Sicoob, 2019).

As regards the Sicredi system, even if it is considered to be a market-focused system, that is to say that it has neither a basis nor a foundation of solidarity in its actions, its participation in the micro-credit offer in the period analyzed (2017 to 2019) was quite significant, as can be seen in Figures 4 and 5. Although Sicredi represents the traditional cooperative credit system (Burigo, 2006; Freitas \& Freitas, 2014; Schroder, 2005) and is not as committed to financial inclusion as the 
cooperatives of the solidarity segment, is the only one of the four systems analyzed that presents, in its reports, data on the offer of microcredit separately.

Figure 3 presents, comparatively, data of the microcredit portfolio, total assets and total volume of deposits of Sicredi for the years 2017 to 2019 and Figure 4 shows the participation (in percentage) the microcredit portfolio in relation to the total assets and deposits of the Sicredi system.

Figure 3: Total Assets, volume of deposits and microcredit portfolio (in R\$ billion) - Sicredi - 2017 to 2019.

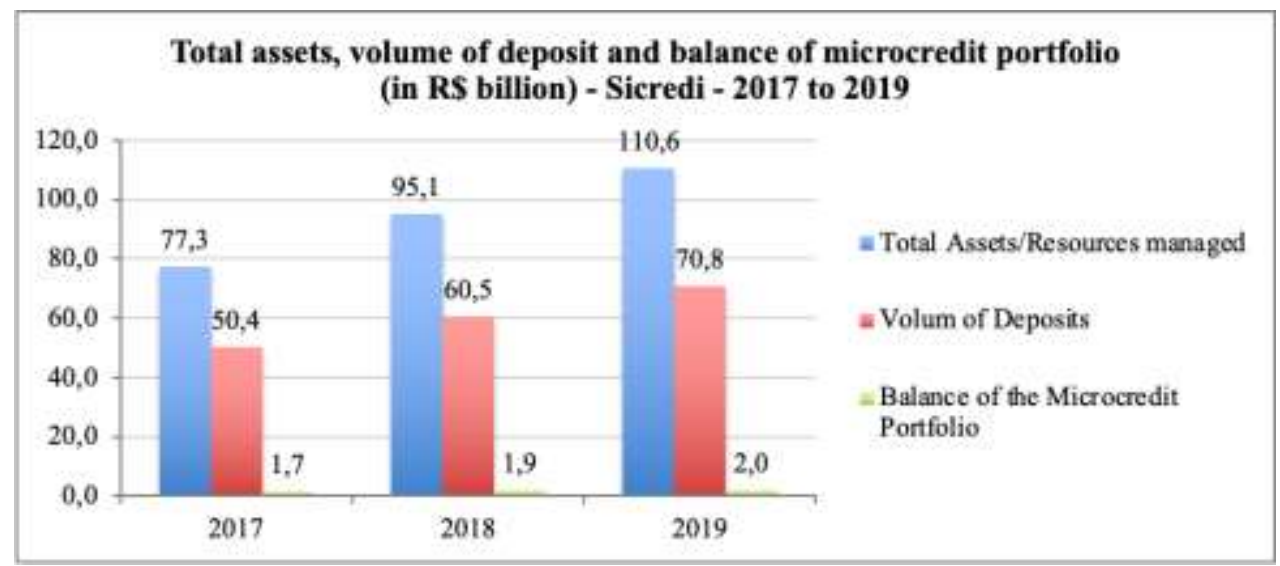

Source: Elaborated by the authors based on data from the financial reports of the confederations.

It can be seen in Figure 4 that the microcredit portfolio grew (where is this evidence?), but at rates lower than the growth rates of assets and deposits, besides having a not very relevant participation in relation to both assets and volume of deposits, despite presenting both in absolute terms and in participation, the best performance in offering microcredit of the four systems analyzed.

Figure 4: Share of microcredit portfolio in relation to total assets and volume of deposits in \% - Sicredi - 2017 to 2019.

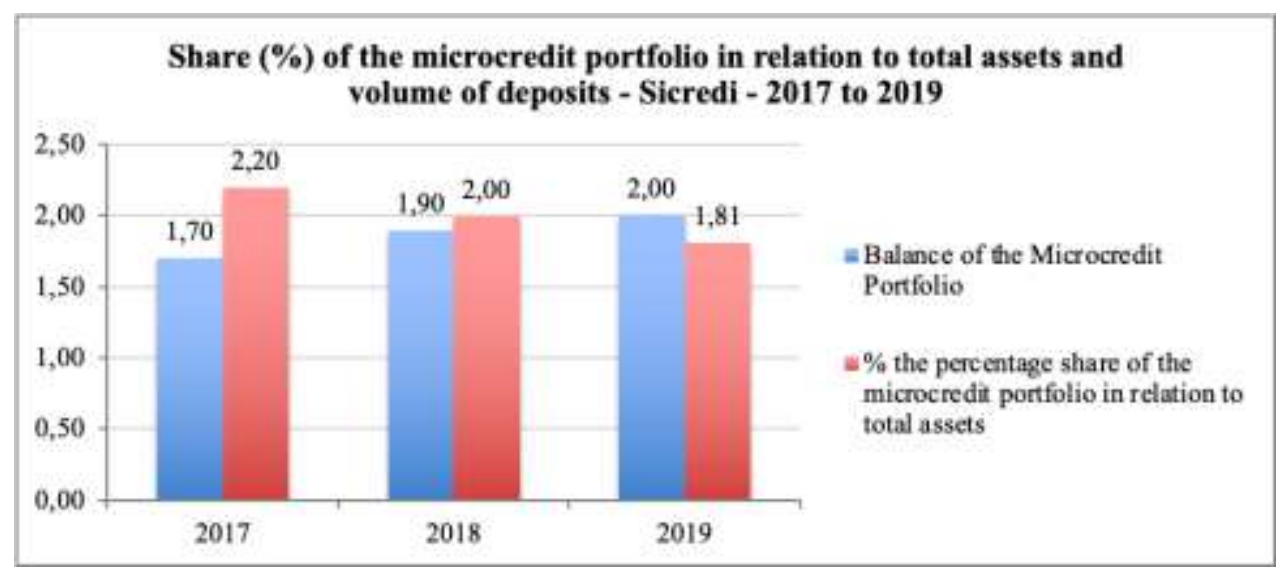

Source: Elaborated by the authors based on data from the financial reports of the confederations.

Figures 5, 6 and 7 present some comparative data of the total assets, total deposit volumes and microcredit portfolios (respectively) of the Brazilian cooperative credit systems analyzed (Cresol, Sicoob, Sicredi and Unicred). The three figures show that the Cresol system, the smallest of the four analyzed in both total assets and volume of deposits, operates the largest microcredit portfolio. On the other hand, the system that manages the largest volume of resources (total assets), Sicoob, admittedly falls short of the expectations of stakeholders and the market about its performance in the offer of microcredit. This 
can be understood in the light of the founding and guiding principles of the cooperative movement of solidarity credit, which, as highlighted earlier, seeks to preserve its original vocation which is the democratization of financial services based, above all, in the offer of microcredit, which, historically, has proved to be one of the main strategies of financial and social inclusion.

It is worth noting that the still incipient microcredit offered by the four cooperative credit systems analyzed follows the same dynamics of the participation of the NCCS in relation to the SFN, which, despite being on an upward trajectory in recent years as mentioned above, in December 2020, according to the BCB (2020b), represented only $3.8 \%$ of total assets, $6.21 \%$ of total deposits, and $5.1 \%$ of the SFN credit portfolio.

Figure 5: Total assets in R \$ billion - Cresol, Sicoob, Sicredi and Unicred Systems - 2017 to 2019.

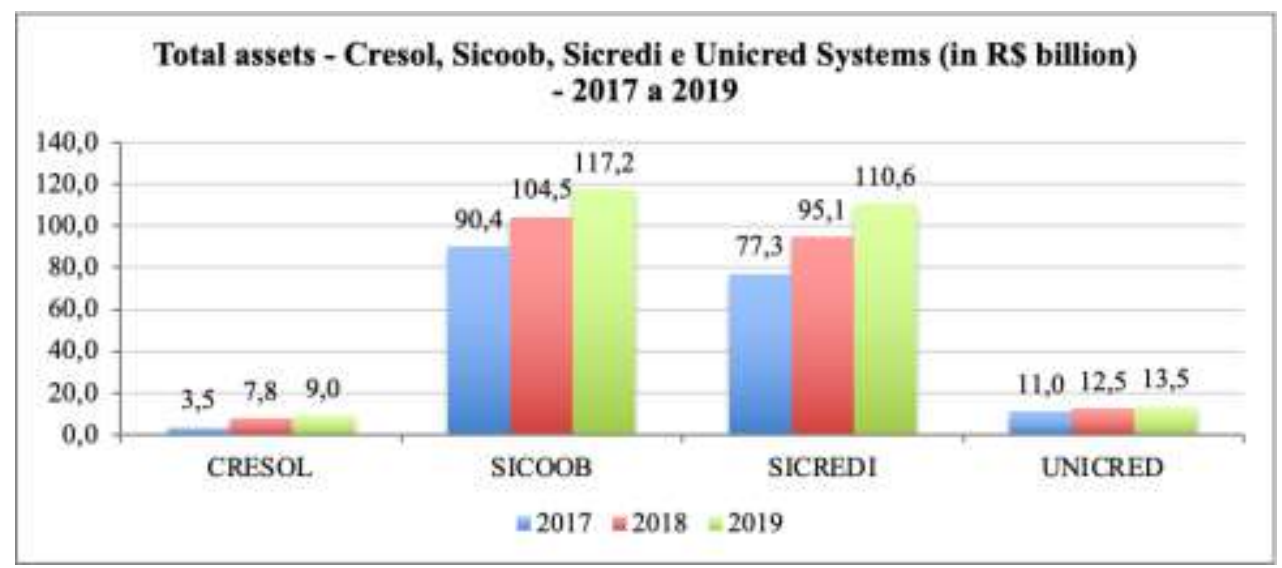

${ }^{1}$ Data from Cresol Confederation (Credit Centers: Cresol Baser, Cresol Central SC/RS, Cresol and Ascoob). Data refers to the total credit portfolio, including on lendings from the BNDES and other FIs. Source: Prepared by the authors based on data from the confederations' financial reports.

Figure 6: Volume of deposits (in R\$ billion) - Cresol, Sicoob, Sicredi and Unicred Systems - 2017 to 2019.

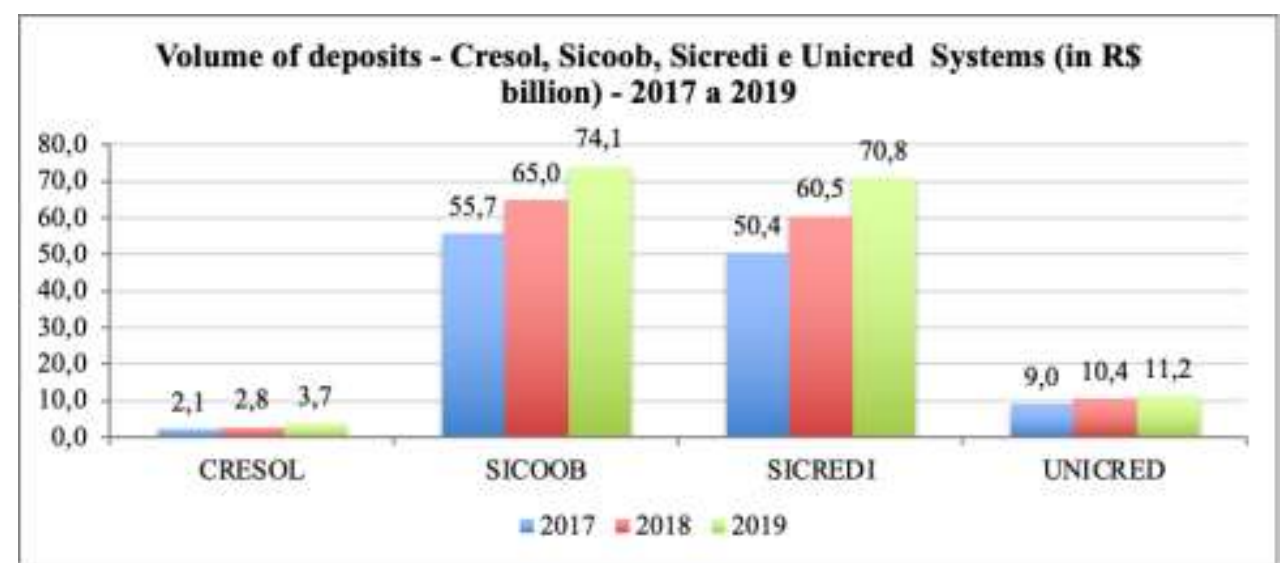

${ }^{1}$ Data from Cresol Confederation (Credit Centers: Cresol Baser, Cresol Central SC/RS, Cresol and ASCOOB). Data refers to the total credit portfolio, including on lendings from the BNDES and other FIs. Source: Prepared by the authors from data from the confederations' financial reports. 
Figure 7: Balance of microcredit portfolio of the Cresol, Sicoob, Sicredi and Unicred systems (in R\$ billion) - 2017 to 2019.

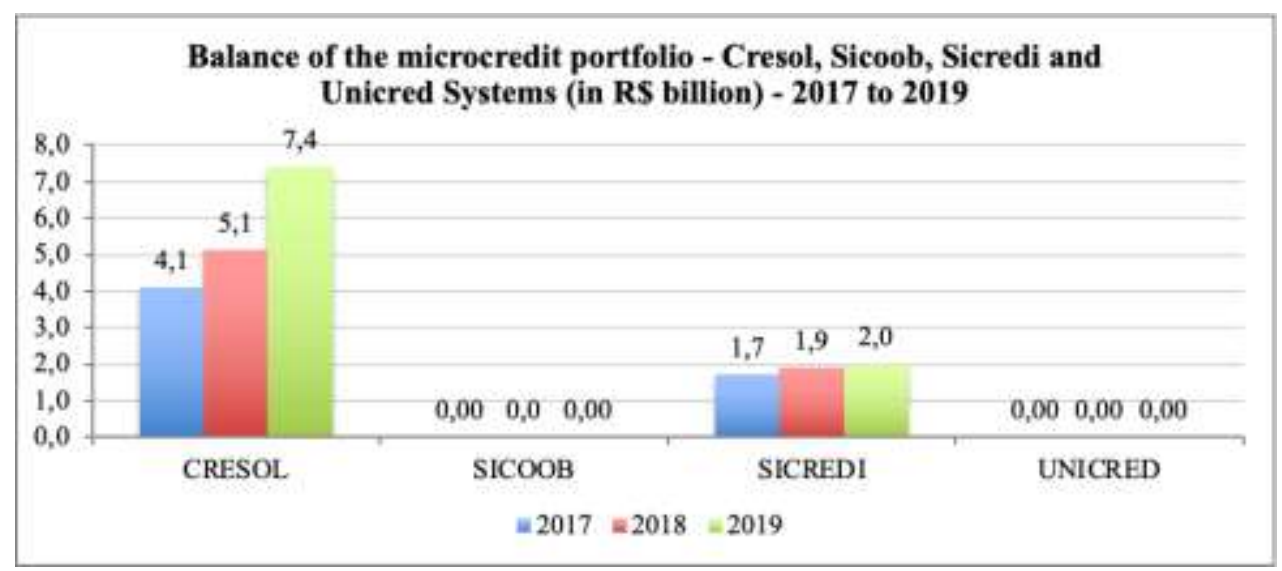

${ }^{1}$ Data from Cresol Confederations (Credit Centers: Cresol Baser, Cresol Central SC/RS, Cresol and ASCOOB). Data refer to the total credit portfolio, including on lendings from the BNDES and other FIs. In 2017, the amount corresponds to R $\$ 1.6$ billion in commercial credit and $\mathrm{R} \$ 2.5$ billion in rural credit; In 2018, $\mathrm{R} \$ 2$ billion in commercial credit and $\mathrm{R} \$ 3.14$ billion in rural credit; In 2019 , $\mathrm{R} \$ 2.7$ billion in commercial credit and R $\$ 4.7$ billion in on lending (rural and corporate). Source: Prepared by the authors from data from the confederations' financial reports.

The overall supply of microcredit, in relation to the SFN, is also considered small by BCB (2015). Data from the Credit Information System (SCR) base date December 2013, published by BCB (2015) showed that, at that date, the microcredit portfolio was $\mathrm{R} \$ 5.3$ billion, relative to 3.1 million credit operations, which represented $0.2 \%$ of the value and $0.4 \%$ of the operations of the National Financial System (SFN). In the period, the FIs that granted microcredit were grouped into four segments - development agencies, banks, credit cooperatives and Credit Society for Micro-entrepreneurs and Small Businesses (SCMs) - and more than $80 \%$ of this amount was granted by three public banks - this is explained, in part, because it is a public policy and a complex product with low margin - (BCB, 2015). The report in question also considers that one of the possible causes for the modest supply of microcredit in the period was the timid participation of credit unions and SCMs less than a third of SCMs and only $6.3 \%$ of credit unions were microcredit providers - (BCB, 2015).

Nevertheless, this picture has been changing. Data from BCB (2020b) point out that in the period between December 2019 and December 2020, there was an increase of $\mathrm{R} \$ 17$ billion (13.5\%) in the amount of the active portfolio of broad microcredit operations and an increase of $5.1 \%$ in the stock of operations. This growth in the volume of microcredit was very close to the $15.8 \%$ increase in the total balance of credit operations in the SFN and is explained by a substantial increase in two of the three groups that compose the broad microcredit, namely free microcredit and oriented productive microcredit (MPO), which grew, respectively, $\mathrm{R} \$ 12.2$ billion (39.5\%) and $\mathrm{R} \$ 2.1$ billion (31.5\%). Microcredit aimed at urban activities, on the other hand, which was most affected by the crisis caused by the Covid-19 pandemic, advanced at twice the speed of total credit in the SFN, pulled by the effect of emergency credit programs, especially Pronampe (BCB, 2020b).

Table 3 shows the participation of each of the cooperative systems analyzed in the total supply of microcredit (broad microcredit). 
Table 3: Participation of the microcredit portfolio of the Cresol, Sicoob, Sicredi and Unicredi systems in relation to the total active portfolio of broad microcredit* -2018 and 2019.

\begin{tabular}{|c|c|c|c|c|}
\hline & \multicolumn{2}{|c|}{2018} & \multicolumn{2}{|c|}{2019} \\
\hline & (R\$ billion) & $(\%)^{* *}$ & (R\$ billion) & $(\%)$ \\
\hline Large active microcredit portfolio & 79,4 & - & 75,3 & - \\
\hline Cresol's microcredit portfolio & 5,1 & 6,42 & 7,4 & 9,82 \\
\hline Sicoob's Microcredit Portfolio & $\mathrm{N} / \mathrm{I}$ & - & $\mathrm{N} / \mathrm{I}$ & - \\
\hline Sicredi's Microcredit Portfolio & 1,9 & 2,39 & 2,0 & 2,65 \\
\hline Unicred's Microcredit Portfolio & $\mathrm{N} / \mathrm{I}$ & - & $\mathrm{N} / \mathrm{I}$ & - \\
\hline
\end{tabular}

Note: No data found for 2017. *The SCR classifies as broad micro-credit operations those carried out to finance productive activities of natural or legal persons, organized individually or collectively, with income or annual gross revenue of up to $\mathrm{R} \$ 200,000.00$ (two hundred thousand reais) - the limit in force pursuant to Resolution 4,713/2019 of the National Monetary Council (CMN), which regulated the value established by Law n 13,636/2018 amended by Law $\mathrm{n}^{\circ} 13,999 / 2020$ to $\mathrm{R} \$ 360,000$ (Three hundred and sixty thousand reais). However, considering that this law was not enacted until 31 March 2020 , the closing date of the 2019 Bank Economy Report, the current limit in Resolution 4,713/2019 (BCB, 2019) was adopted. ${ }^{* *}$ Participation (in \%) of the system's microcredit portfolio in relation to the broad microcredit active portfolio. Source: Prepared by the authors based on data from BCB (2019) and financial reports from the Cresol, Sicoob, Sicredi and Unicred Confederations.

As can be seen in Table 3, the offer of microcredit by the Cresol system went from $6.42 \%$ ( $\mathrm{R} \$ 5.1$ billion reais) in relation to the total active portfolio of broad microcredit ( $\mathrm{R} \$ 79.4$ ) in 2018 to $9.82 \%$ ( $\mathrm{R} \$ 7.4$ billion) in 2019. The Sicred system offered in $2018 \mathrm{R}$ \$ 1,9 billion in microcredit, which represented 2,39\% of the active portfolio total broad microcredit ( R \$ 75,3) increasing the offer to R \$ 2,0 billion reais in $2019-2,65 \%$ of the active portfolio total broad microcredit -. The Sicoob and Unicred systems did not present, in their reports, separate data on the offer of microcredit, as previously mentioned.

According to BCB (2019), the reduction in the size of the active microcredit portfolio (from R 79.4 billion in 2018 to $\mathrm{R} \$ 75.3$ billion in 2019) is probably due to the sharp growth of new payment arrangements such as anticipated receivables, of card arrangements for microenterprises and microentrepreneurs, which may have led to a reduction in demand for microcredit lines. On the other hand, the growth in the share of the credit offered by the SNCC in relation to the SFN, BCB (2019) attributes to the expansion of the instruments for raising resources, such as financial bills, guaranteed real estate bills, rural savings and housing savings, among other factors.

In summary, even with the low representativeness of both the SNCC in relation to the SFN and the supply of microcredit in general in relation to the supply of credit by the SFN, as well as the small participation of the supply of micro-credit by the cooperatives of the four systems analyzed (Cresol, Sicoob, Sicredi and Unicred) in relation to the total portfolio of broad micro-credit, some factors point to an improvement in this picture. The cooperative system has characteristics, as seen, that make it very appropriate for expanding its insertion in the supply of microcredit. One characteristic highlighted by BCB (2020b) is its capillarity. In December 2020, the SNCC concentrated its credit portfolio in municipalities with up to 50 thousand inhabitants ( $48.8 \%$ of the relevant portfolio) to the detriment of the rest of the SFN, which was more present in metropolitan regions with more than 1 million inhabitants - $28 \%$ of the relevant portfolio. Furthermore, $42 \%$ of the credit in municipalities with up to 10 thousand inhabitants is granted by cooperatives against $4.7 \%$ of the credit in municipalities with more than 1 million inhabitants - considered the relevant portfolio - (BCB, 2020b). These findings are corroborated by Mckillop et. al. (2020) when they state that credit unions have a greater impact on the economy of smaller municipalities.

However, Brazilian credit unions still face some challenges to expand their participation in the credit supply, especially microcredit, such as the growth of fintechs and payment institutions - which are offering fast and safe digital services - a threat that can be transformed into opportunities for cooperatives, as well as problems related to communication and marketing, added to the banking concentration in the country, the latter identified in the study by Vilanova (2020). 


\section{Conclusions}

This study aimed to analyze the participation of Brazilian credit cooperatives in the offer of microcredit in the period from 2017 to 2019. To this end, a documentary research was carried out, when data were collected from financial reports published by the institutions that make up the main Brazilian cooperative credit systems, in addition to data from reports published by the Central Bank of Brazil.

The findings allowed us to conclude that: (i) although previous studies, such as Santos et. al. (2019) present evidence that credit cooperatives are the most appropriate financial institutions to work with microcredit according to their origin and characteristics, the offer of microcredit in the analyzed period (2017 to 2019) not very large compared to the size of the as sets and the amount of deposits collected by these institutions; (ii) irrespective of the size of the total deposits and the assets administered, the credit unions; by law, they can work with resources from other Ifs such as transfers of government programs such as PNMPO, Pronampe, BNDES resources, among others, which further enhances the capacity of cooperative institutions to act in the provision of microcredit; (iii) another characteristic favorable to a greater inclusion of credit unions in the offer of microcredit that is not being well used by them is related to its capillarity (they are present in all states), especially in smaller municipalities.

It is concluded, therefore, that most credit unions, although they have significant potential as operators of microcredit and other microfinance products (microinsurance, micro savings), have not acted as expected, despite recent advances in stimulating a greater insertion of them by the public authorities, such as the new Microcredit Law (No. 13.636/18), which updated the Pnmpo and allowed cooperatives to perform some digital operations.

Finally, the evidence brought by this research meets the objective of analyzing the performance of Brazilian credit unions in the supply of microcredit in Brazil, having been identified, through the analyzis, their scarce insertion. The positive aspect is the fact that they recognize, in their reports, this low performance and that some have already taken some initiatives to expand it, such as the creation of a digital account for non-cooperative members by the Sicoob system, aiming to expand both the supply of microcredit and the financial inclusion by going beyond the traditional public of members/cooperative members.

It is worth mentioning that Brazilian credit cooperatives can greatly expand their operations in the supply of microcredit considering their differentiated business model (they do not have profit as an end but as a means and reinvest the surplus in the institution and in the community where it operates) and their wide capillarity (they are distributed throughout the national territory), in addition to the large number of unbanked individuals and municipalities in Brazil. A study by Bülow \& Machado (2020), when evaluating the banking potential of the credit cooperative movement in Brazilian municipalities that do not have any branch, regular or electronic service points, and measuring the unassisted population in these places, found evidence that the Brazilian credit cooperative movement has great capacity for growth and expansion of the scope of its financial products and services, and may benefit more than 1.64 million individuals and 392 municipalities currently without a branch, common or electronic service station, especially in the Northeast, which concentrates $66.35 \%$ of the unbanked population (Bülow \& Machado (2020).

Furthermore, the Central Bank of Brazil recently included in its agenda (Agenda BC\#), actions and guidelines aimed at stimulating competition and the expansion of the credit cooperative movement due to this segment's potential for insertion in the most distant municipalities and poorest regions, namely the North and Northeast, and its ability to foster regional development (BCB, 2019). Among the goals established in the BCB's strategic agenda include: (a) the expectation that cooperativism will now represent $20 \%$ of credit within the National Financial System; (b) the possibility that the service network will be increased by $35 \%$ in the percentage of municipalities served by cooperatives in the North and Northeast regions, which have the lowest percentages of insertion of singular credit cooperatives in their municipalities, with $26 \%$ and $11 \%$, respectively (BCB, 2019). 
Finally, it is hoped that the analyzis developed here can be useful for institutions, borrowers, regulators, policy makers, academics, researchers, and other actors involved in the cooperative and microcredit ecosystem, by bringing new elements of analyzis. It is suggested, then, for future research studies that contemplate a longer period of analyzis, that can be extrapolated, conferring greater external validity to the research findings, as well as qualitative studies in order to provide greater depth to the analyzis.

For future studies, more comprehensive research about other types of microcredit institutions is suggested, such as fintechs and payment institutions that offer digital financial services in general. Also, new investigations that involve a wide population, whose results can be extrapolated and confer greater external validity, as well as examine the context in other countries to provide new insights.

\section{References}

Aghabarari, L., Guettler, A., Naeem, M., Doornik, B. V. (2020). Is There Help Indeed, if There is Help in Need? The case of credit unions during the global financial crisis. Working Papers Series, n. 511, Central Bank of Brazil.

Aghion, B. A. de, \& Morduch, J. (2005). The economics of microfinance. Group (2nd ed.). The MIT Press.

Alves Júnior, A., Freitas, A. F. de, Freitas, A. F. de, Silva, M. G. da, \& Moreira, I. R. J. (2021). Fé, enxada e dinheiro: a socio gênese do cooperativismo de crédito rural solidário em Minas Gerais - Brasil. Research, Society and Development, 10(3), e6110313037. https://doi.org/10.33448/rsd-v10i3.13037

Alves, S. D. da S., \& Soares, M. M. (2004). Microfinanças: democratização do crédito no Brasil - atuação do Banco Central. Brasília: Banco Central do Brasil.

Banco Central do Brasil - BCB - (2015). Panorama do microcrédito. Série cidadania financeira: estudos sobre educação, proteção e inclusão, N 1, BrasíliaDF.

Banco Central do Brasil - BCB - (2019). Panorama do sistema nacional de crédito cooperativo. Data-base: dezembro/2019.

Banco Central do Brasil - BCB - (2019b). Relatório de Economia Bancária. Brasília-DF.

Banco Central do Brasil - BCB - (2020). Microcrédito. Estudo Especial nº 79/2020. In: Relatório de Economia Bancária. Brasília-DF.

Banco Central do Brasil - BCB - (2020b). Crescimento das Cooperativas de Crédito. In: Panorama do Sistema Nacional de Credito Cooperativo.

Barone, F. M., \& Sader, E. (2008). Acesso ao crédito no Brasil: evolução e perspectivas. Revista de Administração Pública, 42(6), $1249-1267$.

Barreto, S. S. (2016). Os fundos rotativos solidários no Brasil. Mercado de trabalho: Conjuntura e análise, n. 60. Ipea.

Bastelaer, T. V. (2000). Does Social Capital facilitate the poor's access to credit? A review of the microeconomic literature. Washington, D.C.: The World Bank. Social Capital Initiative. Working Paper Series no. 8.

Bittencourt, G. A. (2001). Cooperativas de Crédito Solidário: Constituição e Funcionamento. - 2. ed. - Brasília: NEAD (Núcleo de Estudos Agrários e Desenvolvimento Rural).

Bittencourt, G. A., \& Abramovay, R. (2003). Inovações institucionais no financiamento à agricultura familiar: o Sistema Cresol. Revista Economia Ensaios. v. 16, n. 1.p. 179-207.

Bülow, A. M., Machado, L. C. (2020). Potencial de bancarização do cooperativismo de crédito nos municípios brasileiros desassistidos pelo SFN. Prêmio ABDE-BID Edição 2020: Coletânea de Trabalhos. Rio de Janeiro: ABDE (Associação Brasileira de Desenvolvimento).

Burigo, F. L. (2006). Finanças e solidariedade: o cooperativismo de crédito rural solidário no Brasil. Estudos Sociedade e Agricultura.14(2), $312-349$.

Christopoulos, T. P. \& Gonzalez, L. (2017). Achieving family farmers' demands for microcredit through credit unions: a framework for discussion. Revista de Administração Mackenzie - RAM (Mackenzie Management Review), 18(5), 116-143.

Confederação Brasileira da Cooperativas de Crédito - Confebras - (2020). Panorama do Cooperativismo Financeiro no Brasil (2020), Sistema Nacional de Crédito Cooperativo (SNCC). http://www.confebras.coop.br/panorama-do-cooperativismo.

Cresol (2017). Relatório de Atividade Central Cresol Baser. https://cresol.com.br/relatorios/

Cresol (2018). Relatório de Atividade Central Cresol Baser. https://cresol.com.br/relatorios/

Cresol (2019). Relatório de Sustentabilidade. https://cresol.com.br/relatorios/

Feitosa, W. R., Moura, M. J. S. B. de, Barbosa, R., Rossi, F. L. (2022). O instrumento do microcrédito: lealdade do cliente e impactos sociais. Revista de Geopolítica, 13(1), 14-27. 
Freitas, A. \& Freitas, A. (2014). O cooperativismo de crédito no Brasil e a emergência de uma vertente solidária. Revista Brasileira de Gestão e Desenvolvimento Regional (G\&DR), 10(2), 46-74, Taubaté, SP, Brasil.

Fundação Instituto de Pesquisa Econômica - FIPE/Sistema de Crédito Cooperativo - SICREDI (2019). Benefícios econômicos do cooperativismo de crédito na economia brasileira. São Paulo: Relatório Técnico.

Goldszmidt, R., Behr, P., Zucco, C., Lenz, A.-K., Gonzalez, L., \& Valdivia, M. (2021). Microcredit Impacts: Evidence from a Large-Scale Observational Study in Brazil. European Journal of Development Research. https://doi.org/10.1057/s41287-021-00448-3.

International Cooperative Alliance - ICA - (2020). https://www.ica.coop/

Lu, W., Swisher, J. (2020). A comparison of bank and credit union growth around the financial crisis. American Journal of Business, 35(1), 25-44.

Martins, G. A., Theóphilo, C. R. (2007). Metodologia da investigação científica para Ciências Sociais Aplicadas. Atlas.

McKillop, D., French, D., Quinn, B., Sobiech, A. L., Wilson, J. O. S. (2020). Cooperative financial institutions: a review of the literature. International Review of Financial Analysis, 71(C).

McKillop, D., Wilson, J. O. S. (2010). Credit Unions: a theoretical and empirical overview. School of Management at The Queen's University of Belfast, Belfast. $78 \mathrm{p}$.

Namorado, R. (2009). Cooperativismo. In: HESPANHA et. al. Dicionário internacional da outra economia. Almedina.

Organização das Cooperativas Brasileiras - OCB - (2020). https://www.ocb.org.br/ramos.

Pinheiro, M. A. H. (2008). Cooperativas de crédito: história da evolução normativa no Brasil. (6a ed.), Banco Central do Brasil.

Pinho, D. B. O (2004). Cooperativismo no Brasil: da vertente pioneira à vertente solidária. Saraiva.

Santos A. L., Barros, L., Takeda, T., \& Gonzalez, L. (2019). Efeitos de mudanças regulatórias no microcrédito no desempenho financeiro e social de cooperativas de crédito brasileiras. Revista de Contabilidade \& Finanças. 30(81), 338-351.

Santos, A. L. C. (2016). Mudanças regulatórias no microcrédito e desempenho financeiro e social de cooperativas de crédito no Brasil. Tese (Doutorado), Universidade de São Paulo (USP).

Schroder, M. (2005). Finanças, comunidades e inovações: organizações financeiras da agricultura familiar - o sistema Cresol (1995 a 2003). Tese (Doutorado em Ciências Econômicas). Unicamp, Campinas, SP.

Serviço Brasileiro de Apoio às Micro e Pequenas Empresas - Sebrae/Fundação Getúlio Vargas - FGV (2020). O impacto da pandemia de coronavírus nos pequenos negócios. $9^{\mathrm{a}}$ edição. Pesquisa quantitativa on-line (web survey) realizada de 20/11/2020 a 24/11/2020.

Sicoob (2017). Relatório Anual. https://www.sicoob.com.br/web/sicoob/relatorios

Sicoob (2018). Relatório de Sustentabilidade. https://www.sicoob.com.br/web/sicoob/relatorios

Sicoob (2019). Relatório de Sustentabilidade. https://www.sicoob.com.br/web/sicoob/relatorios

Sicredi (2017). Relatório de Sustentabilidade. https://www.sicredi.com.br/site/sobre-nos/relatorios/

Sicredi (2018). Relatório de Sustentabilidade. https://www.sicredi.com.br/site/sobre-nos/relatorios/

Sicredi (2019). Relatório de Sustentabilidade. https://www.sicredi.com.br/site/sobre-nos/relatorios/

Soares, M. M., \& Melo Sobrinho, A. D. (2008). Microfinanças: o papel do Banco Central do Brasil e a importância do cooperativismo de crédito. (2a ed.), Brasília: BCB.

Unicred (2017). Demonstrações Financeiras. Confederação Nacional das https://www.unicred.com.br/institucional/entidade/demonstracoes-contabeis-1

Unicred (2018). Demonstrações Financeiras. Confederação Nacional das Cooperativas https://www.unicred.com.br/institucional/entidade/demonstracoes-contabeis-1

Unicred (2019). Demonstrações Financeiras. Confederação Nacional das https://www.unicred.com.br/institucional/entidade/demonstracoes-contabeis-1

Vilanova, F. C. (2020). As barreiras para o desenvolvimento das cooperativas de crédito no Brasil: uma perspectiva a partir da percepção de valor dos usuários de serviços financeiros. Dissertação (mestrado) - Universidade do Vale dos Rio dos Sinos, Porto Alegre, RS.

Ward, A. M., \& McKillop, D. G. (2005). An investigation into the link between UK credit union characteristics, location and their success. Annals of Public and Cooperative Economics, 76(3), 461-489. 